\title{
Eradication of the Invasive Common Carp, Cyprinus carpio from a Large Lake: Lessons and Insights from the Tasmanian Experience
}

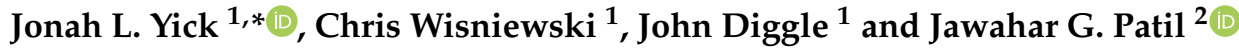 \\ 1 Inland Fisheries Service, 17 Back River Road, New Norfolk, TAS 7140, Australia; \\ chris.wisniewski@ifs.tas.gov.au (C.W.); john.diggle@ifs.tas.gov.au (J.D.) \\ 2 Fisheries and Aquaculture Centre, Institute for Marine and Antarctic Studies, University of Tasmania, \\ Nubeena Crescent, Taroona, TAS 7053, Australia; Jawahar.patil@utas.edu.au \\ * Correspondence: jonah.yick@ifs.tas.gov.au
}

check for updates

Citation: Yick, J.L.; Wisniewski, C.; Diggle, J.; Patil, J.G. Eradication of the Invasive Common Carp, Cyprinus carpio from a Large Lake: Lessons and Insights from the Tasmanian Experience. Fishes 2021, 6, 6. https://doi.org/10.3390/ fishes6010006

Academic Editor: Peter W. Sorensen

Received: 28 November 2020

Accepted: 18 February 2021

Published: 23 February 2021

Publisher's Note: MDPI stays neutral with regard to jurisdictional claims in published maps and institutional affiliations.

Copyright: (c) 2021 by the authors. Licensee MDPI, Basel, Switzerland. This article is an open access article distributed under the terms and conditions of the Creative Commons Attribution (CC BY) license (https:// creativecommons.org/licenses/by/ $4.0 /$ )

\begin{abstract}
Common carp (Cyprinus carpio, L. 1758) are the most abundant pest fish species in Australia, detrimental to ecosystem integrity and values, and in need of suitable management solutions. In January 1995, this destructive pest was discovered in two large, connected Tasmanian lakes-Lakes Crescent $\left(23 \mathrm{~km}^{2}\right)$ and Sorell $\left(54 \mathrm{~km}^{2}\right)$. After an initial assessment, carp were immediately contained to these waters using screens to prevent their escape down-stream, followed by swift legislation to enforce closure of the lakes to the public. Assessment and evaluation of carp numbers occurred throughout the eradication program, with effort focused on Lake Crescent. Beginning with undirected removal, techniques progressively evolved to more sophisticated targeted removal with assistance from biotelemetry, in conjunction with gill netting and electro-fishing. Real-time population estimates and in situ observations resulted in a detailed cumulative understanding of carp population dynamics, behaviour and seasonal habitat choice. This allowed strategic deployment of fences to block access to marshes, and the installation of steel traps within the fences. These gears specifically prevented spawning opportunities, while concurrently capturing mature fish. Following 12 years of adaptive and integrated effort, 7797 carp (fry, juvenile and adult) were captured from Lake Crescent, with the last carp being caught in December 2007. The subsequent 14 years of monitoring has not resulted in the capture of any carp, confirming the successful eradication of carp from Lake Crescent. These management practices have been successfully replicated in the larger Lake Sorell, where 41,499 carp (fry, juvenile and adult) have been removed. It is now estimated that there are few, if any carp remaining. Collectively, the techniques and strategies described here were reliable, and can be applied as a model to control or eradicate pest populations of carp in freshwater lakes elsewhere.
\end{abstract}

Keywords: common carp; invasive; incursion; alien fish; fyke net; pest fish; Lake Sorell; Lake Crescent; biotelemetry

\section{Introduction}

The impacts of invasive species on native species, communities, and ecosystems have been extensively documented [1-4] and recognised as a threat to global biodiversity [1,5], second only to habitat loss. While some aquatic introduced species have had little or no detectable effects, many have been damaging to the environment and human interests [6]. Aquatic invasive species significantly impact economic enterprises such as agriculture and fisheries [7], with freshwater ecosystems particularly at higher risk as they harbour greater biodiversity per surface area than marine and terrestrial ecosystems $[6,8,9]$, and provide more direct human services such as a ready source of potable water.

The invasive common carp Cyprinus carpio, is one of the most widely established freshwater fish globally [10,11], and is the most abundant pest fish species in Australia [12]. It was first introduced in 1859, after being released into numerous ponds in Victoria, but 
never established in the wild [13]. It was not until 1964 when it was released into the Murray River near Mildura, Victoria, that it began to spread throughout Australia [13]. With a distribution of over one million $\mathrm{km}^{2}$, common carp are now established in all states and territories in Australia, apart from the Northern Territory [12-14]. In addition to competing with native and other desirable fish species for both food and space $[13,15,16]$, carp can inflict major environmental and economic costs by reducing water quality $[13,17]$. Carp have also been implicated in macrophyte destruction through direct grazing, physical uprooting of plants, increasing water turbidity, enriching nutrient loads, and reducing invertebrate biomass through predation $[13,18,19]$.

Physical eradication of carp was found to be the most cost effective and environmentally benign option in Tasmania, despite the high level of sustained effort required. The aim here is to detail the steps, strategies, and techniques that were successfully implemented to eradicate carp from Lake Crescent, Tasmania. This was initiated by setting up a designated Carp Management Program (CMP) within the Inland Fisheries Service (IFS) Tasmania, as soon as the carp were discovered in 1995. The integrated strategies employed focused on the exploitation of the biological vulnerabilities of carp (including their specific behaviours), and the optimisation of capture methods. The events and strategies of the CMP in the Tasmanian lakes have been previously summarised in Diggle et al. (2012) [20] and Wisniewski et al. (2015) [21], however this current report aims to provide a refined, and more rigorous update of the successful eradication.

\section{Common Carp in Tasmania}

\subsection{The Discovery of Common Carp in Tasmania}

Carp were first discovered in Tasmania in the mid-1970s, then again in 1980, in several farm dams on the North West coast [20-22]. Given the relatively small size of the dams, all populations were eradicated using rotenone treatments. It wasn't until 28 January 1995, when an angler found the remains of a fish on the banks of Lake Crescent, that a much more serious threat was identified. The fish was handed to the Inland Fisheries Service (IFS) on 30 January 1995, and suspected to be a carp [20].

\subsection{Lakes Crescent and Sorell}

Lake Crescent is a large, shallow, freshwater lake located in the south-east corner of the Tasmanian Central Plateau (Coordinates: Lake Crescent $147^{\circ} 16^{\prime} \mathrm{E}, 42^{\circ} 18^{\prime} \mathrm{S}$ ), and is connected with the upstream Lake Sorell [20] (Figure 1). The lakes are situated at the head of River Clyde catchment, a $97 \mathrm{~km}$ watercourse which eventually drains into the River Derwent. Water temperatures can range from a low of about $0-2{ }^{\circ} \mathrm{C}$ in winter and reach up to $20^{\circ} \mathrm{C}$ in summer (Figure A1) [23]. Snow can occur in any month of the year, and frost events are also common [23]. Lake Crescent $\left(23 \mathrm{~km}^{2}\right)$ is less than half the size of Lake Sorell $\left(54 \mathrm{~km}^{2}\right)$, with average and maximum depths of 1.5 and $3.8 \mathrm{~m}$, and 2.5 and $4.4 \mathrm{~m}$ respectively, at full supply [24,25]. At times of full supply, both lakes have extensive wetland areas that connect to the main lake bodies, which are some of the largest areas of shallow water in Tasmania [26].

The Interlaken Lakeside Reserve in the north-west corner of Lake Crescent is internationally recognised under the Ramsar Convention on wetlands [28]. The wetland supports a diverse assemblage of aquatic macrophytes, including the poorly reserved swamp wallaby-grass (Amphibromus neesii) (currently listed as rare under the Tasmanian Threatened Species Protection Act 1995) [29]. Lake Crescent is a turbid-phytoplankton dominated system [29,30], with phytoplankton biomass 10 times that of the neighbouring Lake Sorell [30]. It is also inhabited by numerous endemic fauna, that includes a snail species Austropyrgus sp., and the golden galaxias fish (Galaxias auratus), which are listed as endangered under the Commonwealth Environment Protection and Biodiversity Conservation Act 1999 [20,21,31,32]. The reserve is an important resting and feeding refuge for many waterbirds, including significant migratory birds. The wetland periodically dries out and when inundated, provides important habitat for macroinvertebrates, frogs and 
fish [29]. The two lakes also support a recreational brown (Salmo trutta) and rainbow trout (Oncorhynchus mykiss) fishery, a commercial fishery for the native short-finned eel (Anguilla australis), and provides water for domestic use and irrigation, which are all of significant importance to the State's economy $[20,27,33,34]$.

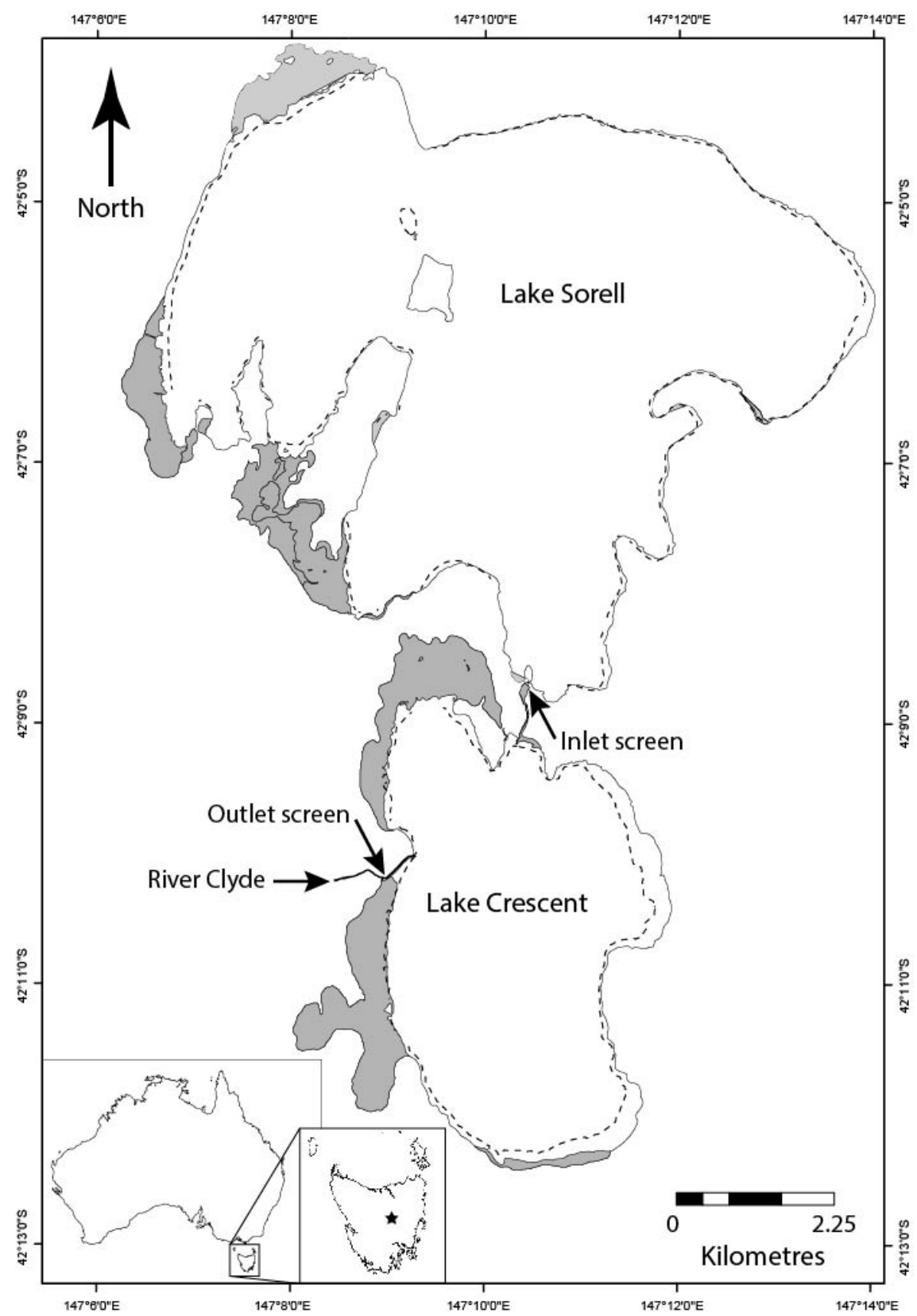

Figure 1. Map of lakes Sorell and Crescent showing the location of the River Clyde, containment screens, wetland areas (shaded grey), and the level of wetland inundation (dotted lines). The integrated management activities contained the carp to these two lakes with eradication achieved in the latter (Adopted from Taylor et al. (2012) [27]). Inset are maps of Australia and Tasmania, with the location of the lakes (star) (Left hand side, bottom).

\section{Developing a Strategy and Approach to Control Carp in Lakes Sorell and Crescent}

The confirmation of carp in the two largest water bodies on the eastern side of Tasmania's central plateau was of immediate concern to the Tasmanian community at large. This triggered an immediate fisheries management response led by the Inland Fisheries Service, Tasmania. 


\subsection{Initial Assessment and Response}

Backpack electro-fishing surveys were undertaken in Lake Crescent on 1 February 1995 , and resulted in multiple carp caught, confirming their presence in this lake. On 6 March 1995, an electro-boat was deployed in Lake Sorell, resulting in the capture of several carp, making it apparent that carp were established in both the lakes [20,21]. Further assessments of both lakes soon determined that Lake Crescent had a relatively large population of carp compared to Lake Sorell. As a result, most of the initial removal effort was focused on Lake Crescent, in an attempt to reduce the population numbers while the density of carp was high. Electrofishing surveys downstream of Lake Crescent were also undertaken annually in the River Clyde catchment, to assess if carp had inadvertently escaped and established in any sections of the river. None were found downstream of Lake Crescent, except for a single carp caught immediately downstream of the Lake Crescent outlet in July 1995 [20]. Electro-fishing boats from New South Wales and Victorian fisheries agencies were procured in February and March 1995, to assist the carp surveys [20,21]. All initial surveys suggested that the carp were contained to lakes Sorell and Crescent. The preliminary fishing effort in the lakes resulted in significant fish-down, giving an indication of the size of the carp population in both lakes, which guided the subsequent management steps.

Following the confirmation of carp in both lakes, a basic containment strategy was implemented, which allowed time to assess the various options [20,21]. Primarily, this involved the prevention of escape or transfer of carp from the Lake Sorell and Lake Crescent populations [22]. Carp could have potentially spread throughout the lower River Derwent via the River Clyde catchment, as far down as Bridgewater (approximately $15 \mathrm{~km}$ north of Hobart, and $60 \mathrm{~km}$ downstream of the lakes system). Containment was achieved by closing the outlet from Lake Crescent. To prevent the risk of further inadvertent human assisted spread (e.g., by anglers) and/or reintroductions [35], Lake Crescent was closed to the public on 18 February 1995. It remained closed until 2004 when carp numbers were deemed low enough that the risk of transfer from the lake was unlikely [20]. The closure included, but was not limited to, angling, duck shooting, boating, wading, swimming, or any activity that results in contact with the water [22].

\subsection{Creation and Implementation of the Adaptive Carp Management Plan}

In the absence of a similar scale eradication attempt anywhere else in the world at the time, it was 'a learn as you go' adaptive management strategy from the outset. To begin with, the State Government initiated a joint agency response consisting of a carp task force which later transitioned to a Carp Working Group (CWG) [20-22]. The initial mission of the CWG was to determine the preferred strategy between suppression (i.e., control of carp population numbers) or eradication. Although contained to the Lake Sorell and Lake Crescent systems, a control strategy alone posed long term risk of translocation and spread to other waterbodies. This directly threatened the multimillion-dollar recreational trout fishing industry, as well as a wide range of endemic aquatic flora and fauna of the state. Therefore, containment with the aim of eradication was determined to be the preferred outcome. On 1 June 1995, the CWG were successful in obtaining additional funding from the Tasmanian Government, which was put towards the establishment of a four person $\mathrm{CMP}$ team, to begin the carp fish-down process.

For eradication of any pest species to be successful, six criteria need to be achieved, which are detailed in Bomford and O'Brien (1995) [35]. The lakes Crescent and Sorell were soon assessed and rendered "closed systems" with an ability to contain carp. Complemented by sustained support from the government and community, it became clear that eradication was a feasible option [20]. Consequently, the objective of the CMP was to eradicate carp from Tasmanian waters and, in the meantime, to minimise the impact of carp on Tasmania, from economic, recreational and ecological points of view.

The following broad strategies were adopted to achieve this objective [20,21]. They are: 
1. Contain carp to the lakes Sorell/Crescent catchment;

2. Reduce the existing carp population;

3. Eradicate carp;

4. Develop and implement a water management plan to ensure water supply for reliant townships and irrigators, while facilitating 1-3 above;

5. Prevent introduction of carp to new water bodies and it's reintroduction to cleared waters (from both inter and intrastate sources) and;

6. Implement legislative and communication strategies to minimise damage to inland fisheries and tourism, while facilitating the above objectives in a timely fashion.

The next obvious step was to determine the most feasible method of achieving eradication. Three main options were considered; draining the lakes, poisoning the lakes and physical removal of carp $[20,21]$. Due to bathymetrical limitations and the potential adverse environmental impacts, draining or poisoning the lakes were not considered. As a result, an integrated approach with physical removal as the cornerstone was deemed the best option, and implemented at the outset.

Although techniques and strategies evolved with time and growing knowledge, the physical removal remained the central theme. This was complemented by containment, spawning prevention and real-time estimation/calibration of population size. Collectively, these four elements were deemed adequate to address criteria one to three [35] for eradication.

\section{Following the Plan: Reducing Carp Abundance in Lake Crescent}

The capture and removal of carp in Lake Crescent evolved with time and was reliant on using a range of techniques, alone or in combination. Typically, all size classes of carp were caught concurrently. However, specific techniques were developed to target carp fry ( $<50 \mathrm{~mm}$ fork length) and juveniles (50-250 $\mathrm{mm}$ fork length), as part of the recruitment prevention strategy (See Step 3 below).

\subsection{Step 1: Containment}

First, the two lakes and the upper River Clyde were closed to the public, then containment screens were installed at the outlet of Lake Crescent (Figure 2). To further facilitate transfer of water downstream (for domestic, stock and irrigation use, as well as to restore environmental flows), the outlet structure at Lake Crescent was fitted with an internal screen and the outlet reopened on 24 February 1995 (Figure 2) [21]. The screens (Figure 2) constituted a physical barrier to carp by screening objects to 1 or $5 \mathrm{~mm}$, using interchangeable stainless steel mesh [22]. The $1 \mathrm{~mm}$ mesh was used from the start of October until the end of April each year, throughout the carp spawning period, to minimise the risk of eggs or fry escaping containment [20,22]. From May until the end of September, the mesh size was increased to $5 \mathrm{~mm}$ or greater reflecting the increased size of carp fry and allowing increased flow releases over the wetter winter months [20,22]. This approach balanced the greater risk of uncontrolled spill/overflow, and the potential escape of fry, juvenile, and adult carp. Observations indicated that all carp fry would outgrow the $5 \mathrm{~mm}$ mesh by the end of April [20]. The screens required manual cleaning, an aspect increasingly labour intensive as the flow rates increased [20]. Importantly, this screening strategy was successful in containing carp over a 25-year period. Initially, a course $25 \mathrm{~mm}$ grate was installed at the outlet of Lake Sorell on 7 August 1995, to prevent the movement of adult carp from Lake Crescent upstream into Lake Sorell [20]. In 2001, $5 \mathrm{~mm}$ screens were installed at the Lake Sorell outlet structure, which completely isolated the lakes from each other, preventing both upstream and downstream movement of carp [22]. 


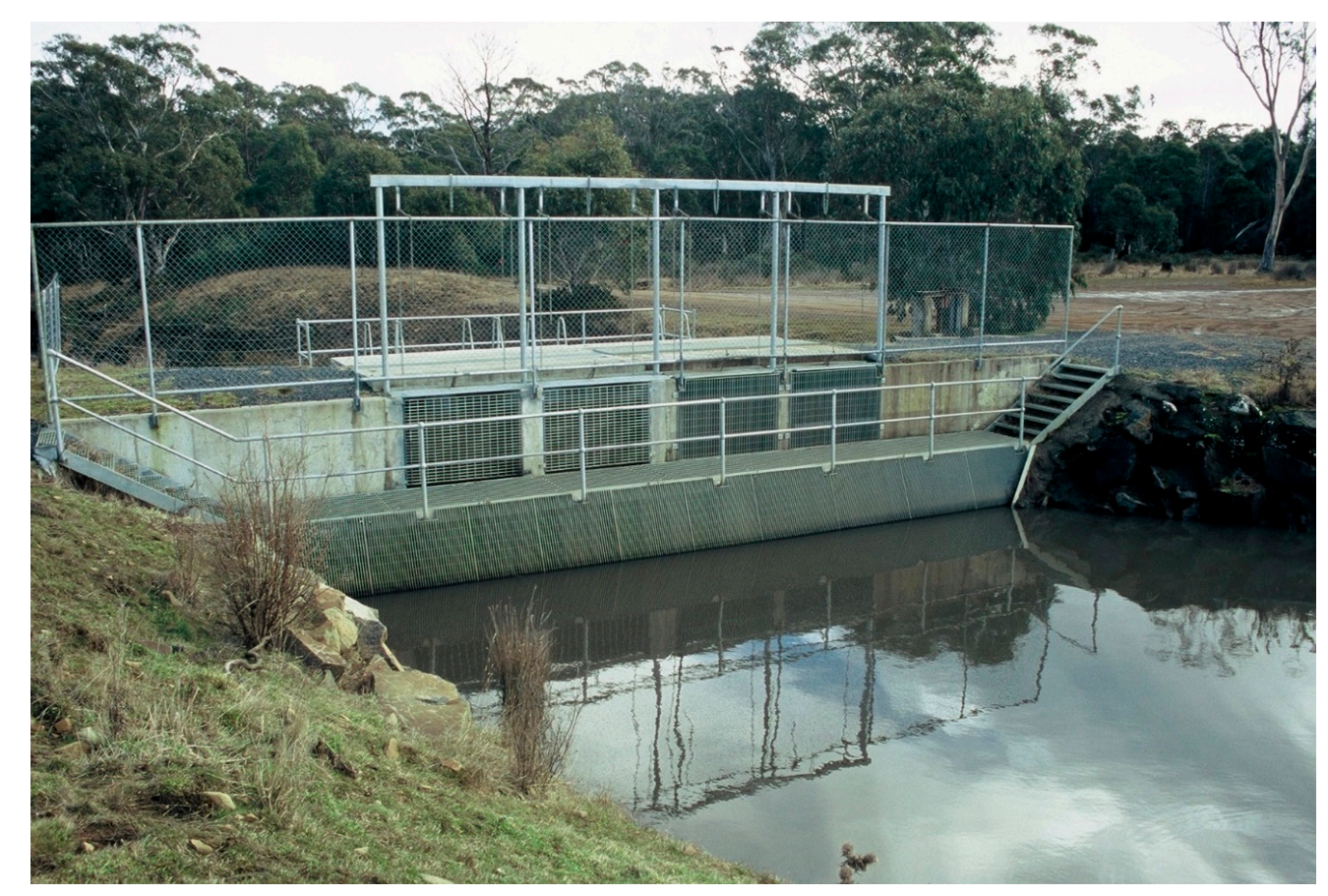

Figure 2. The Lake Crescent outlet structure showing the coarse external screens.

Modifications were also implemented around the lake to prevent uncontrolled and unscreened spill/overflow [22]. Specifically, levees were constructed to direct all flood waters through an overflow channel [22]. The channel was screened with $5 \mathrm{~mm}$ mesh to prevent the passage of fry, juvenile and adult carp [22]. In addition to the screening infrastructure, an active compliance operation around the lakes was also undertaken, as well as a public awareness program. This was followed by on-going electrofishing surveys in the River Clyde that indicated that carp had not spread downstream, nor established selfsupporting populations. These downstream electrofishing surveys, conducted annually since 1995, did not detect any carp populations, confirming the containment strategy was successful, reinforcing the possibility of eradication.

\subsection{Step 2: The Carp Fish-Down and Associated Strategies}

The CMP began fishing-down carp in February 1995 (Table 1) [20,33]. All quantitative data associated with the eradication has been summarized in Table 1 , with detailed analyses of population estimation and seasonal distribution of carp in Lake Crescent described in two separate studies $[27,34]$. In the early stages of the program there was no knowledge of preferred habitat or fish movement under the local conditions. Therefore initial carp removal strategies were basic, relying on visual observations of fish aggregations and undirected electro-fishing (backpack and boat) or net fishing (gill and seine nets) [20,21]. It was soon identified that for all sized carp to be at risk of capture, a range of gear types were necessary for effective fish-down, and therefore implemented from the outset. Although the gear types evolved and changed with time, they were categorised as primary or secondary techniques based on their catch efficiency for a given season. Specifically, the primary technique refers to the gear type/s that resulted in the highest proportion of carp caught, while the secondary technique refers all other gear types that collectively caught a small proportion of carp, in a given season (Table 1). Specific techniques were developed to target and remove each life stage of carp [20]. For example, the routine collection of length-frequency information derived from capture data provided information on age structure and growth rates of carp in the lake. This information provided insights into gear selectivity that was essential for predicting and deploying suitable gear types (e.g., gill net mesh size) on a regular basis, including forward planning for upcoming fishing seasons, so all cohorts in the population, at a given time, could be fished most effectively [20,36]. 
Table 1. Summary of techniques and strategies used to eradicate carp from Lake Crescent (1995-2010).

\begin{tabular}{|c|c|c|c|c|c|}
\hline Season * & $\begin{array}{l}\text { No. of Carp } \\
\text { Caught }\end{array}$ & $\begin{array}{c}\text { Primary } \\
\text { Technique }\end{array}$ & $\begin{array}{c}\text { Secondary } \\
\text { Technique }\end{array}$ & $\begin{array}{l}\text { Annual } \\
\text { Strategy }\end{array}$ & Description \\
\hline
\end{tabular}

94/95

234

SN, E

CT, LC, DS

$\begin{array}{ccccc}95 / 96^{\dagger} & 1300 & \text { SN, E } & \text { E, GN } & \text { CT, LC, DS } \\ 96 / 97^{\dagger} & 1731 & \text { GN+TC+E } & \text { FN } & \text { CT, LC, DS } \\ 97 / 98 & 1547 & \text { GN+TC+E } & \text { FN } & \text { CT, LC, DS } \\ 98 / 99 & 1554 & \text { GN+TC+E } & \text { SN, FN, PN } & \text { CT, LC, DS } \\ 99 / 00 & 800 & \text { GN+TC, SN, E } & \text { FN } & \text { CT, LC, DS } \\ 00 / 01{ }^{\dagger} & 261 & \text { GN+TC+E } & \text { FN } & \text { CT, LC, DS } \\ 01 / 02 & 210 & \text { GN+TC+E } & \text { SN, FN } & \text { CT, LC, DS } \\ 02 / 03 & 57 & \text { GN+TC+E } & \text { FN } & \text { CT, LC, DS }\end{array}$

$03 / 04$

60

$\mathrm{GN}+\mathrm{TC}+\mathrm{E}$

CT, LC, F, DS

$\begin{array}{ccccc}04 / 05 & 24 & \text { TP } & \text { GN, TC, FN, E } & \text { CT, F, DS, RS } \\ 05 / 06 & 11 & \text { GN+TC+E } & \text { TP, FN } & \text { CT, F, DS, RS } \\ 06 / 07 & 5 & \text { GN+TC+E } & \text { CT, F, DS, RS } \\ 07 / 08 & 3 & \text { GN+TC+E } & \text { CT, F, DS, RS } \\ 08 / 09 & 0 & \text { GN+TC+E } & \text { CT, F, DS, RS } \\ 09 / 10 & 0 & & \text { CT, F, DS, RS } \\ \text { Total } & 7797 & & \end{array}$

GN-Gill Net, E-Electro-fishing (backpack and boat), SN-Seine Net, TC_-Transmitter Carp, TP_-Trap, FN-Fyke Net, PN-Pound net. CT-Containment Screens, LC —-Lake Closure, RS-Recruitment Survey, DS-Downstream Surveys (electrofishing), F-Fence, +-Indicates techniques which are used in combination. *-Season is in line with Australian financial year (1 July to 30 June). ${ }^{* *-P r i m a r y}$ technique refers to the gear type/s responsible for dominant (highest proportion of carp caught) capture of carp for the season. ***-Secondary technique refers to the gear type/s other than the primary for the season (small proportion of carp caught). $\uparrow-$ Indicates a spawning event. Note: All fencing removed in September 2013. Containment screens at outlet of Lake Crescent removed in August 2014. Monitoring of Lake Crescent is on-going post 2010. Downstream and recruitment surveys are still ongoing.

From 1995 to 1996 seine netting was the primary technique, along with electro-fishing and to a lesser extent, gill nets. Due to a higher density of carp at the outset, these fishing techniques proved very efficient, with over 1500 carp caught in the first two years (Table 1). In late 1996, it became apparent that the fish-down efforts employed by the CMP were making a significant impact on the population, as catch per unit effort (CPUE) began dropping, and the capture of carp became increasingly difficult [20]. The CMP began looking into new techniques to improve the effectiveness of locating fish, with the use of biotelemetry adopted in 1997 [37]. 
Wild male carp were surgically implanted with appropriately sized radio transmitters in their gut cavity and then released back into the lakes [20,21,37]. Adult females were not used as transmitter carp to minimise recruitment risk. It was predicted that transmitter carp would begin mixing back with the wild population in the lakes and hence betray their locations. Transmitter carp were located daily, and were used as indicators of carp activity, movement, distribution and range [27,38]. On 10 March 1997, the first nine adult male transmitter carp were released into Lake Crescent [20,22]. On 9 April 1997 the first transmitter aggregation was targeted and resulted in 202 carp captured [22]. From that point through to 2009, the use of gill nets, transmitter carp (Judas carp), and electro-fishing in combination, became the primary technique for locating and capturing carp, particularly adults (Table 1). The technique was highly effective and resulted in the capture of most carp in the aggregations. The high catch efficiency when using transmitter carp in combination with nets was also observed in studies conducted in the USA [38]. Winter aggregations of carp in three Midwestern lakes were targeted using transmitter carp and seine nets, where $94 \%$ of carp in the aggregations were removed [38].

The gill nets used to target adult carp ranged in mesh size from 4 to 7 inches (102 to $178 \mathrm{~mm}$ ), with the exact specifications of the nets detailed in Walker and Donkers (2003) [36]. The carp were enmeshed in gill nets in three main ways [39]: wedged-held tightly by the mesh around the body, gilled-prevented from backing out of the net by a mesh caught behind the operculum and/or tangled-held by projections, usually spines in the mesh. The susceptibility of carp to entanglement by their spines (dorsal and anal), provided a broader size range of catchability for the gill nets, particularly with the finer monofilament mesh. Gill nets were only set during daylight hours, and were removed from the lake at the end of each day.

The daily movements of transmitter carp were first tracked and monitored from a boat using a radio telemetry receiver attached to a large boat-mounted directional antenna (Figure 3). Typically, the boat was driven parallel to the shore, approximately $250 \mathrm{~m}$ from the shoreline. Once a transmitter carp (or group of transmitter carp) was detected in the shallows, care was taken not to spook or startle the aggregation, and the boat was carefully parked on shore, a safe distance away. A small hand-held antennae was then connected to the receiver, and the aggregation was further pin-pointed on foot by wading (two person team). A first gill net (usually the smallest mesh size $2.5 \mathrm{inch}$ ) was carefully waded and set around the area of the transmitter carp, while the second person continued to monitor the position of the transmitter carp with the receiver. This net was always set from shore to shore, to ensure all carp in the vicinity of the transmitter carp were enclosed within the net. The secondary gill nets $(3,4,5,6$ and 7 inch mesh) were set inside the smaller meshed outer net, with increasing (the largest mesh on the inside) mesh size ensuring all sized carp were vulnerable to capture. The areas inside the nets were also systematically electro-fished with the backpack electro-fishers and / or the electro-boat, in order to herd all carp into the nets. The transmitter carp caught in the aggregation were detected first, quickly removed from the net, and released back into the lake to avoid injury and damage. On average, ten active male transmitter carp were maintained in the lake. Re-captured transmitter carp with expired batteries, incidental mortalities, or in poor condition, were replaced with new healthy male transmitter carp [22].

The radio telemetry enabled delineation of inter-seasonal and inter-annual patterns of carp movement and habitat choice in response to changes in lake water level and water temperature (Figure A1) [27]. The resulting knowledge was then used for carp removal, identifying life cycle vulnerabilities, recruitment prevention, and resource rationalisation [20]. Specifically, it facilitated targeted removal of carp by establishing a detailed understanding of carp movement, behaviour and habitat preferences in the lakes [20,27]. Radio telemetry was also critical in locating spawning sites, allowing early intervention through liming or spot poisoning with rotenone. 


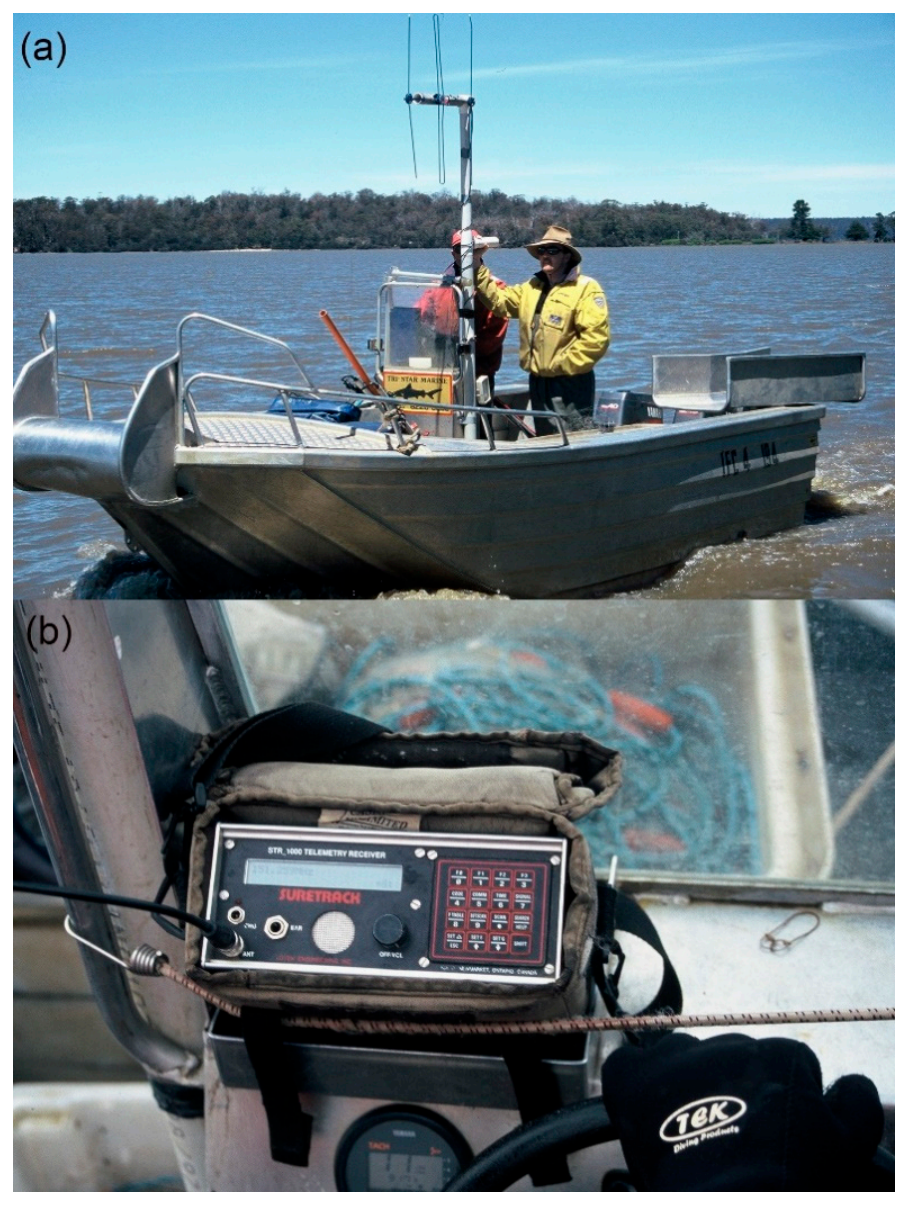

Figure 3. A CMP work boat with a directional antenna installed (a), hooked up to a Lotek telemetry receiver $(\mathbf{b})$ for tracking and monitoring transmitter carp.

\section{Population Estimation}

It was essential to estimate the population abundance of carp accurately and as frequently as possible, to assist the ongoing fish-down efforts and to allow timely management decisions [20]. This aided planning of fishing effort, including allocation of resources, and to monitor the success of the eradication program $[20,33,40]$. Although estimating population numbers can be challenging or near impossible in large lakes, a mark recapture method based on a model developed by Petersen (1896) [41], which proved to be accurate [34], was used. Specifically, deployment of a combination of gear types (to minimise capture bias), use of radio transmitter carp to increase capture efficiency, and the adoption of a reverse-Schnabel approach, resulted in an accurate population estimation in Lake Crescent [34]. These estimates assisted in making several informed management decisions which included the effort/time required to eradicate a cohort, the estimated number of fish remaining, and ongoing CPUE based population estimates within the lake. This information was useful in communicating the program outcomes, and garnering sustained socio-political support including funding. More significantly, the estimates were central to support the management and legislative decisions to declare Lake Crescent free of carp, and its reopening to the public for fishing and recreational activities.

\section{Step 3: Preventing and Eliminating Recruitment}

Preventing and eliminating carp recruitment was a key strategy in the eradication of carp from Lake Crescent. It occurred throughout the fish-down process, either to prevent/capture mature carp accessing spawning habitat, to actively survey for potential spawning events or to respond to spawning events. 
Cooler temperature, particularly during winter, resulted in comparatively slower growth, therefore Tasmanian carp matured more slowly than those on mainland Australia [20]. Male carp in Lake Crescent took a minimum of three years to mature (spermiate) and females, four years. However, some females did not mature until seven years of age [20]. The movement and aggregation of mature carp triggered by the urge to spawn made them particularly vulnerable for capture, by both passive gears as well as active targeting [20]. As males matured at least a year earlier, they were susceptible for earlier capture in traps/fyke nets, providing an opportunity to remove most mature males prior to females in the cohort maturing, further aiding the prevention of spawning.

Spawning of the carp is known to occur in spring and summer at temperatures around $17-25^{\circ} \mathrm{C}$, in shallow, wetland areas [22,42-44]. The number of eggs produced by a female can vary depending on size, age and condition [13]. On mainland Australia, it is estimated that a female carp can produce over one million eggs per year [13]. The temperature data collected from Lake Crescent indicates suitable temperatures for viable spawning are present each year, usually from November to February. This restricted window, in part, allowed implementation of a focused and targeted spawning prevention strategy. In Lake Crescent, the carp have also been observed spawning in water temperatures as low as $11^{\circ} \mathrm{C}$ [22]. However, there is no evidence of successful recruitment from eggs spawned at such low temperatures [22].

\subsection{Spawning Prevention by Blocking Adults}

To ensure removal exceeded the rate of population increase [35], spawning prevention was critical. In Lake Crescent, this was initiated in 2004 (Table 1), by installing $200 \mathrm{~m}$ of heavy gauge chicken wire mesh (approximately $50 \mathrm{~mm}$ in diameter) around prime spawning habitats (shallow, macrophyte rich wetland areas) [22,45]. The fences were also exploited by installing lockable steel traps at vantage points along the fence, such as near drains and creek outlets and inlets (Figure 4) [22,45]. These traps were particularly efficient at capturing mature carp that were attempting to push into the wetlands for spawning, at times of rising lake levels and warming conditions in spring. However, the fences could not completely block access to the wetlands during periods of high lake levels. The efficiency of these traps would peak for a few months of the year (October-November) when the spawning cues were present, as they preferentially removed fish which were reproductively primed, thus preventing both spawning and future recruitment [45]. For example, in the first year of installation, these traps installed within the fences accounted for a large percentage of carp captured, and were the primary technique for the 2004/05 season (Table 1) [45]. Of the 115 carp caught over the 2004/05 season, 63 (55\%) were caught in the traps, and mainly over the peak spawning period in October and November [45].

\subsection{Egg and Fry Removal}

The preferred action plan was to prevent spawning from occurring in the first place, through careful monitoring of environmental cues, in conjunction with monitoring transmitter carp movements, and preventing access to breeding habitat. However, when eggs were detected, a combination of physically removing the affected substrate, in addition to isolating and poisoning the spawning beds, proved to be most effective [20,21]. Carp lay sticky eggs in shallow water amongst submerged macrophytes. When necessary, spawning beds were detected and marked by visual survey, followed by the localized application of hydrated lime (Limil ${ }^{\circledR}$ ) to rapidly raise the $\mathrm{pH}$ level (above 11.0) and kill developing embryos [20]. All stages of carp are vulnerable to alkaline stress in excess of $\mathrm{pH} 9.0$ [20]. The caustic effect of the reactive lime appeared to have an added detrimental effect on the developing embryos. Following liming, the sites were monitored using visual inspections and fine mesh net sweeps to detect any surviving larvae. 


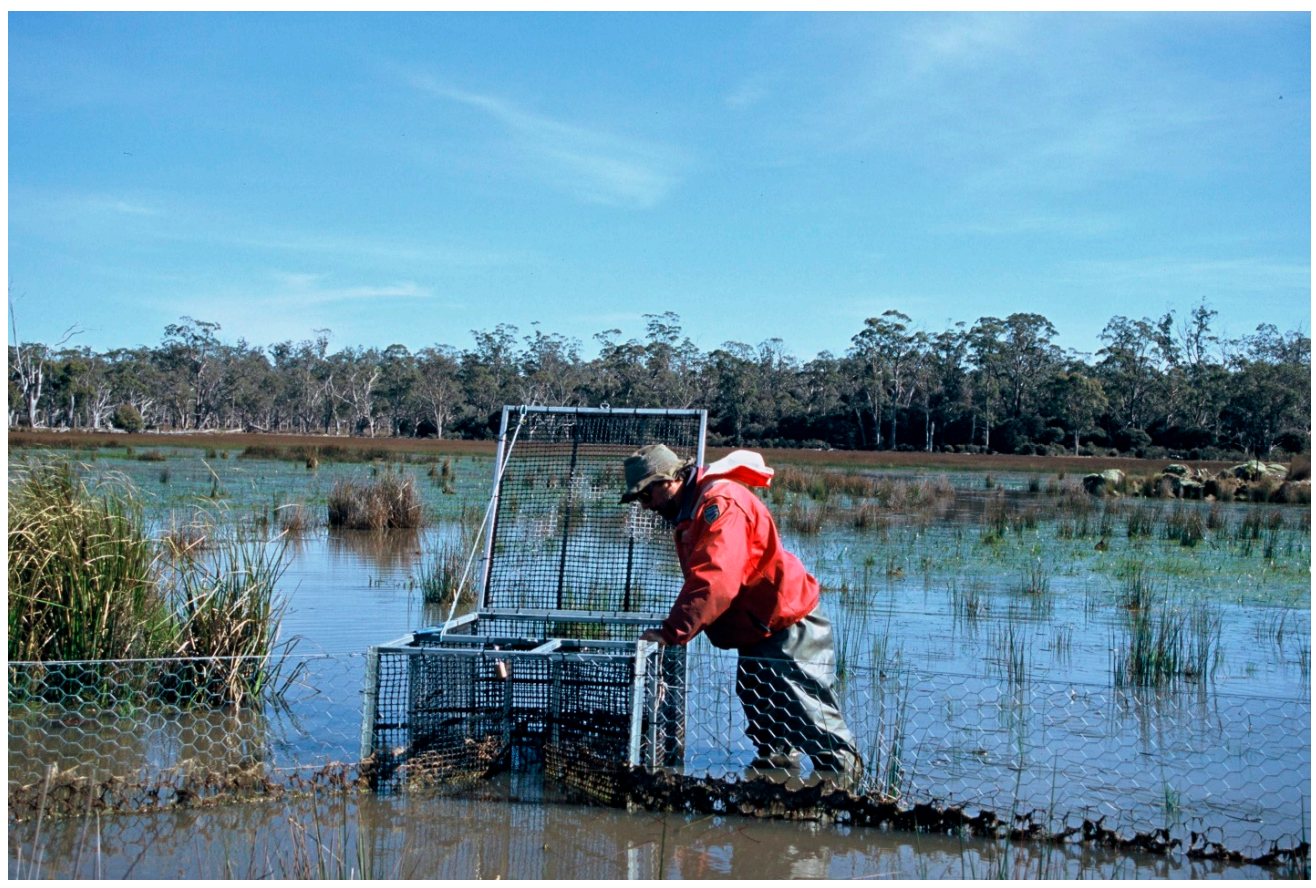

Figure 4. The wire fences that were installed to prevent carp from accessing potential spawning habitat, with lockable traps set at strategic locations. The large expanse of wetlands can be seen behind the fence and trap.

Eight weeks after hatching, the surviving fry began dispersing into the wetlands [20]. The abundance of fry ( $<50 \mathrm{~mm}$ fork length) could be reduced while they were inhabiting the wetlands by dropping water levels (either naturally or artificially). Falling water levels concentrated the young carp into depressions and channels, as the receding water drew them away from the wetlands. These aggregations were located and backpack electrofished, and/or poisoned by spot rotenone applications [20]. Although the efficacy of these techniques were not quantified, they were collectively effective.

\subsection{Juvenile Carp Removal}

Once maturing past the fry stage ( $<50 \mathrm{~mm}$ fork length), juvenile carp (defined here as 50-250 $\mathrm{mm}$ fork length) tended to disperse out of wetlands into the main lake, and forage around the margins [20]. For the next 15-24 months, carp of this size became vulnerable to capture using fyke nets set in the shallows, and strongly responded to increases in temperature of the shallow margins around the lake. During warm settled weather, carp of this size class pushed into the shallows and formed feeding aggregations [20]. The fyke nets used consisted of single $5 \mathrm{~m}$ wing, $800 \mathrm{~mm}$ high D shaped entrance, three internal hoops, and $18 \mathrm{~mm}$ stretched mesh. Small meshed gill nets ( $2.5 \mathrm{inch}$ ) combined with electrofishing, also became standard techniques for targeting small carp, or determining whether spawning had occurred $[20,22]$. The use of seine nets was also effective at catching all sizes of carp (including juveniles), with good catches made when aggregations were detected over soft bottom and shallow water.

\subsection{Recruitment Surveys}

It was essential to detect the frequency and magnitude of any recruitment events, in order to plan the most appropriate and effective management strategy $[20,21]$, where recruitment is defined as the presence of carp fry ( $<50 \mathrm{~mm}$ fork length). It was particularly important to identify these events as early as possible so appropriate intervention, such as liming of spawned eggs, isolation and/or spot poisoning of nursery grounds, and choice of appropriate capture gear for targeting could be implemented [20]. To detect spawning and recruitment events an ongoing systematic annual recruitment survey was 
adopted [20]. Specifically, this involved visual inspections of high-risk spawning habitat, fine mesh dip net sweeps, and backpack electro-fishing in areas of known breeding habitat, or where transmitter carp were known to frequent. This was also in conjunction with an annual lake wide fyke net survey, that was used for detecting any cryptic recruitment event/s reliably [20]. Data collected suggested that any carp recruited during the peak spawning period (November-February) would have grown sufficiently large and mobile to be captured by fyke nets set perpendicular to the shore, during the scheduled annual surveys later in the season [20]. These annual recruitment surveys have been ongoing in Lake Crescent since 2004 and have continued despite the last carp capture in 2007 (Table 1). This aspect is likely to remain until carp are completely eradicated from Tasmania.

\section{Step 4: Final Eradication and Monitoring}

After nine years of intensive fish-down efforts using a range of techniques, the remaining number of carp left in Lake Crescent was estimated to be very low. As a result, Lake Crescent was re-opened to the public in 2004, while fishing efforts continued and were focused on removing the last few carp. The use of male transmitter carp (combined with gill nets and electrofishing) was still the key technique for carp detection and capture. However, the installation of wire fences with steel traps in 2004 also proved to very efficient.

\subsection{Opening the Lake to the Public}

In August 2004, it was determined that the remaining carp population in Lake Crescent was so low that the risk of spread via human activities was unlikely, and therefore the lake was re-opened to the public [45]. Fish-down efforts continued despite opening, while ensuring recreational fishers did not interact with the gears.

\subsection{Continued Fish-Down Efforts}

Over the 2004/05 season, the majority of carp were caught in the fish traps installed within the wire fences, while a smaller number were caught using transmitter carp, electrofishing and gill nets in combination [45]. The installation of these new fences prevented mature carp from accessing the spawning habitat within the marshes. Between 2005 to 2006 there were numerous occasions when transmitter carp were captured by the traps, however no other wild untagged carp were found with them [46]. To entice what may be trap-shy carp that may have evaded capture, chemoattraction traps were deployed. This involved priming an odour-donor female carp with pituitary extract and holding it securely in an enclosure behind a trap. This allowed an odour plume to disperse into the lake, potentially attracting other mature carp [47]. One such trapping event (on 31 October 2005) accounted for 9 fish (all males), including a male transmitter carp, which was quite significant considering only 11 fish were caught from the lake after that event [46]. Moreover, a follow up study later demonstrated that mature carp are particularly chemo-attuned during breeding season and hence susceptible for capture by this technique [48]. This finding supports previous work suggesting that a F prostaglandin-based spawning pheromone released by ovulated carp is attractive [49], and could prove useful in their control [50].

During the 2007/08 season, 15 transmitter carp aggregations were targeted with gill nets and electro-fished, with 14 of these events resulting in the capture of only transmitter carp, indicating there were very few carp remaining in the lake [51]. In December 2007, two transmitter carp were detected in shallow water, in response to a significant rain event, combined with warm, humid weather. This particular aggregation resulted in the capture of two tagged male carp and a single wild female carp, which turned out to be the last carp caught out of Lake Crescent (Figures 5 and 6) [51]. 


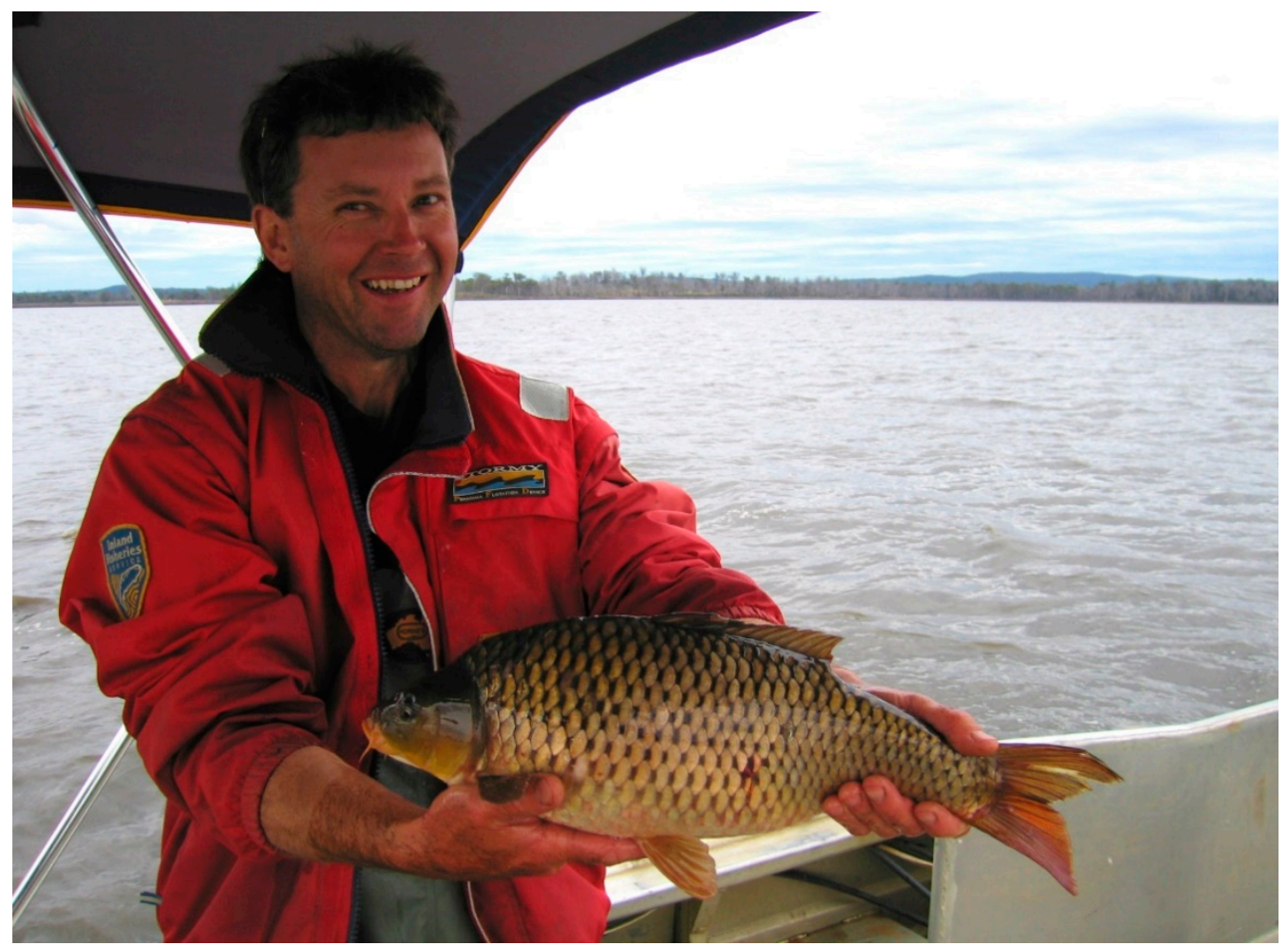

Figure 5. The last carp caught from Lake Crescent.

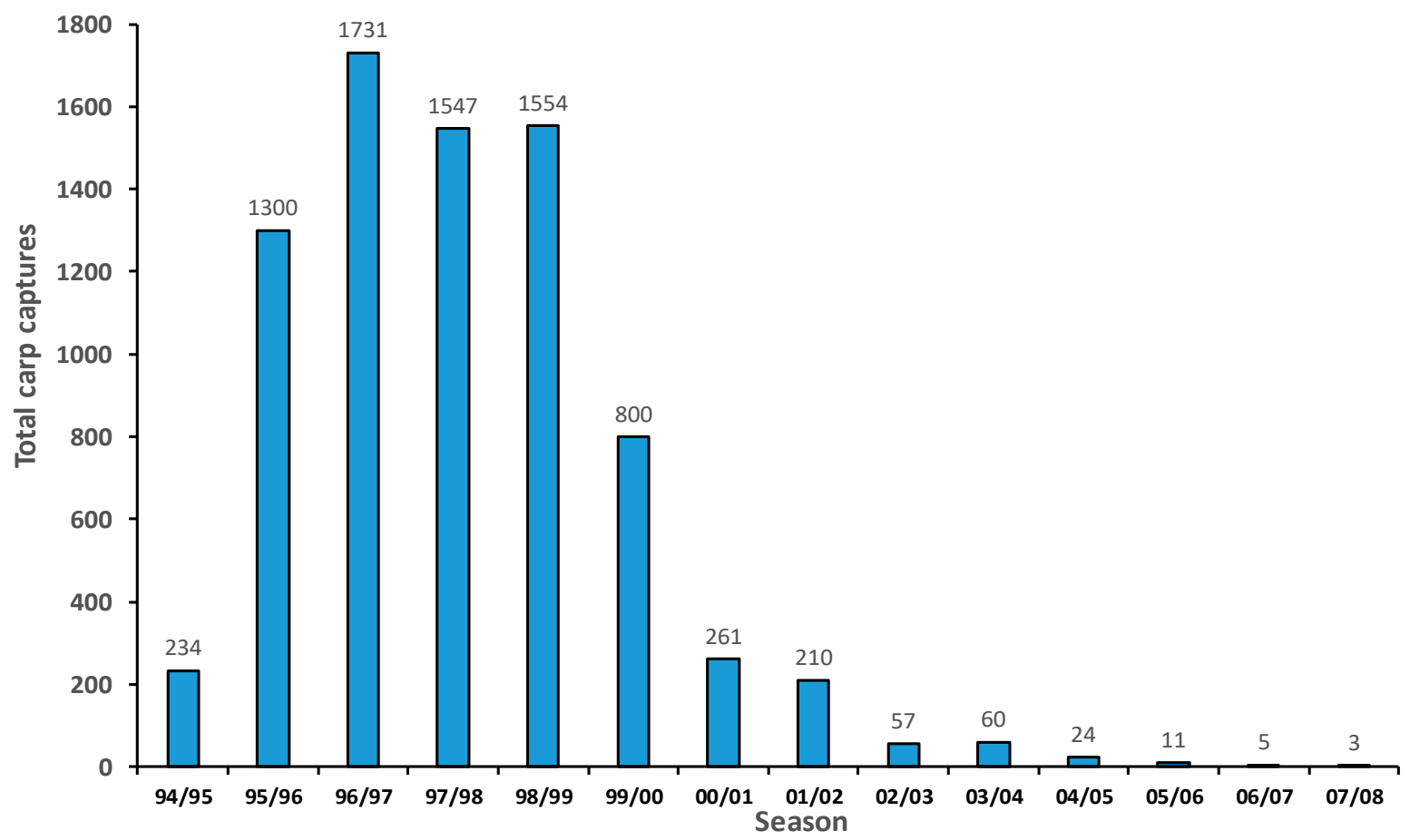

Figure 6. The total number of all carp caught in Lake Crescent from 1995 to 2007, with the last carp caught in 2007.

\subsection{Ongoing Monitoring}

After this event, transmitter carp were monitored for the next two years, with no other wild fish captured $[52,53]$. All transmitter carp were removed from the lake in December 2009, followed by months of intensive surveying for recruitment events [53]. Monitoring 
for recruitment involved electro-fishing, spot rotenone poisoning at known aggregation sites and multiple fyke net surveys around the lake [53]. In addition, commercial eel fishers were permitted to fish Lake Crescent which significantly increased fyke netting effort [53]. Despite the extra effort, no further carp were caught from the lake, verifying the carp free status of Lake Crescent. However, in lieu of an as yet unconfirmed carp free status of the upstream sister Lake Sorell, annual recruitment surveys are ongoing with no carp caught for the last 14 years in Lake Crescent.

\section{Summary and Lessons Learned}

Despite the challenges of the high fecundity of carp, the large expanse of the lake, and relatively cryptic nature of the threat (i.e., compared to terrestrial incursions), the eradication of carp from Lake Crescent was successful. This is particularly remarkable, given the limitations associated with multiple use conflicts including the need to protect the natural values of the lake and maintain the conservation status of the surrounding wetlands. In all, it took 12 years to eradicate the carp population from Lake Crescent, employing mostly physical removal approaches, whilst retaining the natural, social, and in large part economic values of the lake throughout the 12-year campaign.

One of the many challenges faced in eradicating a pest species from an aquatic habitat is knowing when it is finally achieved. We now know the last wild carp was removed from Lake Crescent in December 2007. Several years of fishing effort was applied after this capture to validate the eradication, with recruitment surveys also used to verify success. Fishing effort and lessons learned have since been applied successfully to the last remaining Tasmanian carp population in Lake Sorell.

The integrated and multifaceted approach was the key feature which resulted in the eradication of carp from Lake Crescent. This involved using a range of gear types and techniques in combination with one another during the fish-down, whilst containing carp to the system and preventing/eliminating recruitment at the earliest opportunity. The need and ability to learn and adapt continuously with changing environmental conditions and capture efficiency with decreasing density, were also crucial. Through the Lake Crescent experience, it was apparent that any given carp cohorts can be fished-down systematically within a window of about seven years. However, the most difficult aspect was blocking spawning, despite having reduced the population. The inability to prevent every spawning event meant the introduction of new cohorts, which prolonged the eradication process.

It is difficult to put an exact monetary value on the eradication of carp from Lake Crescent, as the fish-down in Lake Sorell was also undertaken concurrently, albeit intermittently. However, from inception of the Carp Management Program in 1995, to the declaration of carp eradication from Lake Crescent in 2009, a total cost of AU\$ 6.5 million was incurred. As a result of the Lake Crescent experience, extensive improvements were made possible to the gear types and fish-down strategies currently used in the Lake Sorell eradication campaign. This includes gill nets which select for a wide size class of carp, combined with over-night netting. The recruitment prevention strategies in Lake Sorell are also more effective, with the use of polypropylene barrier nets to replace the fences, and various layers of gill net permanently installed behind the barrier nets in the spawning season, for additional security. These improvements would have made a substantial difference if employed in Lake Crescent, especially if they were utilised from the outset, and may have reduced the eradication time frame significantly. Replicating these strategies elsewhere in a similarly invaded habitat is possible, with an estimated eradication time frame of about 7-10 years, with a particularly focused and intensive fishing effort, during the peak spawning season.

At present, over $99 \%$ of the original carp population in Lake Sorell have been removed, and it is estimated that there are few, if any carp remaining. Consistent with the approach in Lake Crescent, the control order was lifted in February 2020 allowing Lake Sorell to be re-opened to the public, after 25 years of intermittent closures. The CMP expects to complete the eradication of carp from Lake Sorell in the next two years. The Tasmanian 
experience clearly demonstrates that an integrated physical removal and containment strategy can be successfully applied to eradicate common carp from large freshwater lakes. With enough resolve, socio-political support and funding, the Tasmanian approach is a viable control technique for application elsewhere.

Author Contributions: Individual authors contributed as follows: Manuscript conceptualization J.L.Y.; program design and methodology J.D., C.W.; data collection J.D., C.W.; writing-original draft preparation J.L.Y., J.G.P.; writing-review and editing J.L.Y., J.G.P., C.W. and J.D. All authors have read and agreed to the published version of the manuscript.

Funding: The Carp Management Program was primarily funded by the Tasmanian State Government, with support from the Federal Government. It was also assisted by a Fisheries Research and Development Corporation (FRDC) grant (Project No. 2000/182).

Institutional Review Board Statement: Not applicable.

Informed Consent Statement: Not applicable.

Acknowledgments: We thank past and present field staff from the Carp Management Program and the Inland Fisheries Service for their input and support. Thanks to Helen O'Neill and Rob Freeman for assisting during the review process. Special thanks also to Professor Peter Sorensen, the guest editor for providing extensive comments and feedback during the review process which substantially improved the manuscript.

Conflicts of Interest: The authors declare no conflict of interest.

\section{Appendix A}

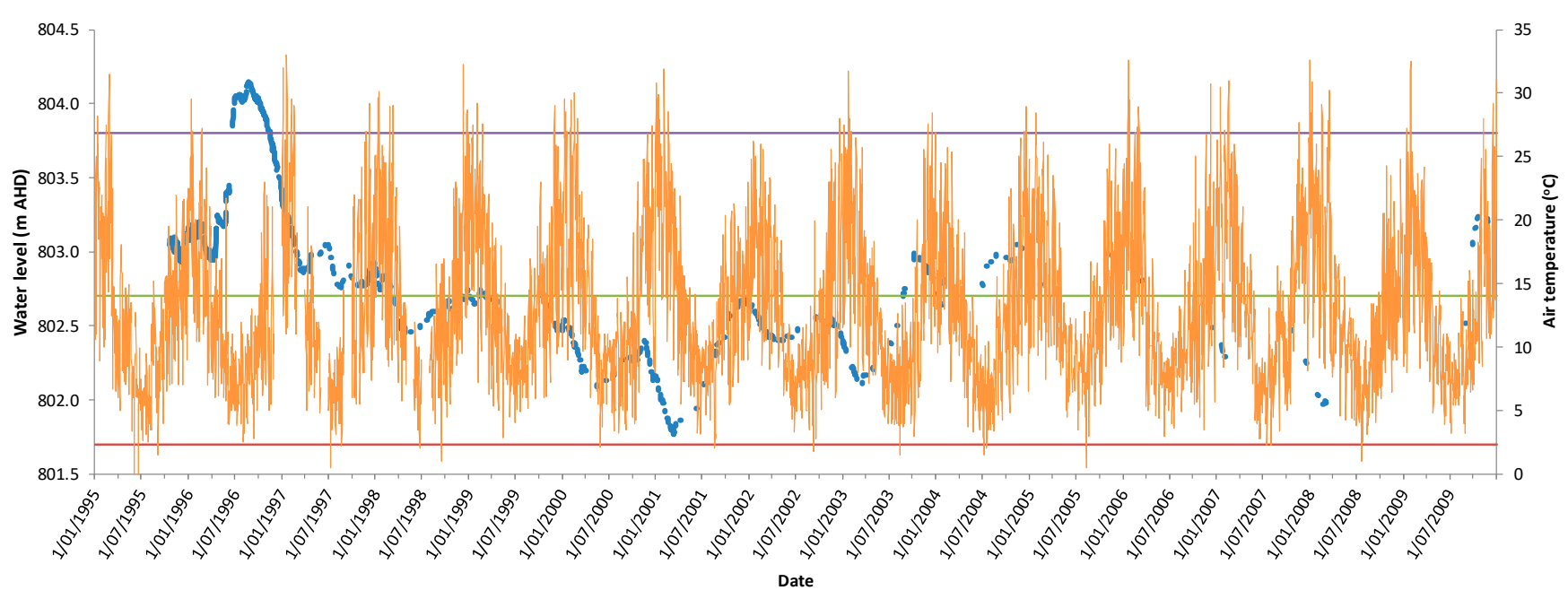

Lake Crescent level — Sill level — Wetland level — Full supply level _ Max air temperature

Figure A1. Lake Crescent lake levels from 1995 to 2009, in relation to the full supply, wetland, and sill levels of the lake. Daily maximum air temperature taken from Lake St Clair National Park is also plotted in conjunction (Downloaded from www.bom.gov.au). Note: Lake level data is deficient at certain periods.

\section{References}

1. Lowe, S.; Browne, M.; Boudjelas, S.; De Poorter, M. 100 of the World's Worst Invasive Alien Species: A Selection from the Global Invasive Species Database; The Invasive Species Specialist Group: Auckland, New Zealand, 2000. Available online: http://www.issg.org/ pdf/publications/worst_100/english_100_worst.pdf (accessed on 8 April 2020).

2. Simberloff, D. Impacts of introduced species in the United States. Consequences 1996, 2, 13-22.

3. Clavero, M.; García-Berthou, E. Invasive species are a leading cause of animal extinctions. Trends Ecol. Evol. 2005, 20, 110. [CrossRef]

4. Elton, C.S. The Ecology of Invasions by Animals and Plants, 1st ed.; Methuen \& Co. Ltd.: London, UK, 1958. 
5. Walker, B.; Steffen, W. An overview of the implications of global change for natural and managed terrestrial ecosystems. Conserv. Ecol. 1997, 1, 1-17. [CrossRef]

6. Havel, J.E.; Bruckerhoff, L.A.; Funkhouser, M.A.; Gemberling, A.R. Resistance to desiccation in aquatic invasive snails and implications for their overland dispersal. Hydrobiologia 2014, 741, 89-100. [CrossRef]

7. Lovell, S.J.; Stone, S.F.; Fernandez, L. The economic impacts of aquatic invasive species: A review of the literature. Agric. Resour. Econ. Rev. 2006, 35, 195-208. [CrossRef]

8. Dudgeon, D.; Arthington, A.H.; Gessner, M.O.; Kawabata, Z.I.; Knowler, D.J.; Lévêque, C.; Naiman, R.J.; Prieur-Richard, A.H.; Soto, D.; Stiassny, M.L. Freshwater biodiversity: Importance, threats, status and conservation challenges. Biol. Rev. 2006, 81, 163-182. [CrossRef]

9. Balian, E.V.; Segers, H.; Martens, K.; Lévéque, C. The freshwater animal diversity assessment: An overview of the results. Hydrobiologia 2008, 595, 627-637. [CrossRef]

10. Bajer, P.G.; Sorensen, P.W. Using boat electrofishing to estimate the abundance of invasive common carp in small Midwestern lakes. North Am. J. Fish. Manag. 2012, 32, 817-822. [CrossRef]

11. Sorensen, P.W.; Bajer, P.G. Carp, common. In Encyclopedia of Biological Invasions; Simberloff, D., Rejmanek, M., Eds.; University of California Press: London, UK, 2011; pp. 100-104.

12. Koehn, J.D. Carp (Cyprinus carpio) as a powerful invader in Australian waterways. Freshw. Biol. 2004, 49, 882-894. [CrossRef]

13. Koehn, J.; Brumley, A.; Gehrke, P. Managing the Impacts of Carp; Bureau of Rural Sciences: Canberra, Australia, 2000.

14. Winker, H.; Weyl, O.L.; Booth, A.J.; Ellender, B.R. Life history and population dynamics of invasive common carp, Cyprinus carpio, within a large turbid African impoundment. Mar. Freshw. Res. 2011, 62, 1270-1280. [CrossRef]

15. Fletcher, A.R.; Morison, A.K.; Hume, D.J. Effects of carp, Cyprinus carpio L., on communities of aquatic vegetation and turbidity of waterbodies in the lower Goulburn River basin. Mar. Freshw. Res. 1985, 36, 311-327. [CrossRef]

16. Brumley, A.R. Cyprinids of Australasia. In Cyprinid Fishes: Systematics, Biology and Exploitation; Winfield, I.J., Nelson, J.S., Eds.; Springer: Dordrecht, The Netherlands, 1991; pp. 264-283.

17. Bajer, P.G.; Sorensen, P.W. Effects of common carp on phosphorus concentrations, water clarity, and vegetation density: A whole system experiment in a thermally stratified lake. Hydrobiologia 2015, 746, 303-311. [CrossRef]

18. Matsuzaki, S.S.; Usio, N.; Takamura, N.; Washitani, I. Contrasting impacts of invasive engineers on freshwater ecosystems: An experiment and meta-analysis. Oecologia 2009, 158, 673-686. [CrossRef]

19. Sorensen, P.W.; Bajer, P.G. Case studies demonstrate that common carp can be sustainably reduced by exploiting source-sink dynamics in Midwestern lakes. Fishes 2020, 5, 36. [CrossRef]

20. Diggle, J.W.; Patil, J.G.; Wisniewski, C. A Manual for Carp Control: The Tasmanian Model; Invasive Animals Cooperative Research Centre: Canberra, Australia, 2012.

21. Wisniewski, C.D.; Diggle, J.D.; Patil, J.G. Managing and Eradicating Carp: A Tasmanian Experience. In New Zealand Invasive Fish Management Handbook; Collier, K.J., Grainger, N., Eds.; LERNZ (The University of Waikato) and Department of Conservation: Hamilton, New Zealand, 2015; pp. 82-89.

22. IFS. Inland Fisheries Service, Carp Management Program Report Lakes Crescent and Sorell 1995-June 2004; Inland Fisheries Service: Hobart, Australia, 2004.

23. DSEWPC. Interlaken Lakeside Reserve Ramsar Site Ecological Character Description; Department of Sustainability, Environment, Water, Population and Communities: Canberra, Australia, 2012.

24. Hardie, S.A. Current Status and Ecology of the Golden Galaxias (Galaxias Auratus); Inland Fisheries Service: Hobart, Australia, 2003.

25. Uytendaal, A. Water Clarity in Two Shallow Lake Systems of the Central Plateau, Tasmania, Australia. Honours Thesis, University of Tasmania, Hobart, Australia, 2006.

26. Kirkpatrick, J.B.; Tyler, P.A. Tasmanian wetlands and their conservation. In The Conservation of Australian Wetlands; McComb, A.J., Lake, P.S., Eds.; Surrey Beatty \& Sons Pty: Sydney, Australia, 1988; pp. 1-16.

27. Taylor, A.H.; Tracey, S.R.; Hartmann, K.; Patil, J.G. Exploiting seasonal habitat use of the common carp, Cyprinus carpio, in a lacustrine system for management and eradication. Mar. Freshw. Res. 2012, 63, 587-597. [CrossRef]

28. UNESCO. Convention on Wetlands of International Importance, Especially as Waterfowl Habitat; UNESCO: Paris, France, 1994.

29. Heffer, D.K. Wetlands of Lakes Sorell and Crescent: Conservation and Management; Inland Fisheries Service: Hobart, Australia, 2003.

30. Cheng, D.M.H.; Tyler, P.A. Lakes Sorell and Crescent-A Tasmanian paradox. Int. Rev. Gesamten Hydrobiol. Hydrogr. 1973, 58, 307-343. [CrossRef]

31. Cleary, C. Habitat Preferences of the Endemic Hydrobiid Gastropod. "Austropyrgus" sp., and Other Aquatic Gastropods from Lakes Sorell and Crescent, Central Plateau, Tasmania. Honours Thesis, University of Tasmania, Hobart, Australia, 1997.

32. Hardie, S.A. Conservation Biology of the Golden Galaxias (Galaxias auratus) (Pisces: Galaxiidae). Ph.D. Thesis, University of Tasmania, Hobart, Australia, 2007.

33. Diggle, J.; Day, J.R.; Bax, N.J. Eradicating European Carp from Tasmania and Implications for National European Carp Eradication; Inland Fisheries Service: Hobart, Australia, 2004.

34. Donkers, P.; Patil, J.G.; Wisniewski, C.; Diggle, J.E. Validation of mark-recapture population estimates for invasive common carp, Cyprinus carpio, in Lake Crescent, Tasmania. J. Appl. Ichthyol. 2012, 28, 7-14. [CrossRef]

35. Bomford, M.; O’Brien, P. Eradication or control for vertebrate pests? Wildl. Soc. Bull. 1995, 23, $249-255$. 
36. Walker, R.M.; Donkers, P. An Examination of the Selectivity of Fishing Equipment in Relation to Controlling Carp (Cyprinus carpio) in Lakes Sorell and Crescent, 2nd ed.; Technical Report No. 2; Inland Fisheries Service: Hobart, Australia, 2011.

37. Macdonald, A.; Wisniewski, C. The Use of Biotelemetry in Controlling the Common Carp (Cyprinus carpio) in Lakes Crescent and Sorell, 2nd ed.; Technical Report No. 1; Inland Fisheries Service: Hobart, Australia, 2011.

38. Bajer, P.; Chizinski, C.; Sorensen, P. Using the judas technique to locate and remove wintertime aggregations of invasive common carp. Fish. Manag. Ecol. 2011, 18, 497-505. [CrossRef]

39. Hamley, J.M. Review of Gillnet Selectivity. J. Fish. Board Can. 1975, 32, 1943-1969. [CrossRef]

40. Donkers, P.D. An Investigation into the Abundance of European Carp (Cyprinus carpio) in Lakes Sorell and Crescent; Technical Report No. 3; Inland Fisheries Service: Hobart, Australia, 2003.

41. Petersen, C.G.J. The yearly immigration of young plaice in the Limfjord from the German Sea. Rept Dan. Biol Sta 1896, 6, 1-48.

42. McDowall, R.M. New Zealand Freshwater Fishes: A Natural History and Guide; Heinemann Reed MAF Publishing Group: Auckland, New Zealand, 1990.

43. Brumley, A.R. Family Cyprinidae-Carps, minnows. In Freshwater Fishes of South-Eastern Australia, 2nd ed.; McDowall, R.M., Ed.; Reed: Chatswood, Australia, 1996; pp. 99-106.

44. Penne, C.R.; Pierce, C.L. Seasonal distribution, aggregation, and habitat selection of common carp in Clear Lake, Iowa. Trans. Am. Fish. Soc. 2008, 137, 1050-1062. [CrossRef]

45. IFS. Inland Fisheries Service, Carp Management Program Annual Report Lakes Crescent and Sorell July 2004-June 2005; Inland Fisheries Service: Hobart, Australia, 2005.

46. IFS. Inland Fisheries Service, Carp Management Program Annual Report Lakes Crescent and Sorell July 2005-June 2006; Inland Fisheries Service: Hobart, Australia, 2006.

47. Patil, J.G.; Wisniewski, W. Hypohysation: A Technique for Deployment of Odour Donor Fish to Control the Common Carp (Cyprinus carpio), 2nd ed.; Technical Report No. 5; Inland Fisheries Service: Hobart, Australia, 2011.

48. Adair, B.J.; Purser, G.J.; Patil, J.G. Peripheral olfactory structures and maturity-related crypt receptor neuron kinetics in the olfactory epithelium of carp Cyprinus carpio (L.): Implications for carnal vulnerability and pest management. Mar. Freshw. Res. 2018, 69, 1604-1613. [CrossRef]

49. Lim, H.; Sorensen, P.W. Common carp implanted with prostaglandin F2 $\alpha$ release a sex pheromone complex that attracts conspecific males in both the laboratory and field. J. Chem. Ecol. 2012, 38. [CrossRef] [PubMed]

50. Sorensen, P.W.; Johnson, N.S. Theory and application of semiochemicals in nuisance fish control. J. Chem. Ecol. 2016, 42, 698-715. [CrossRef] [PubMed]

51. IFS. Inland Fisheries Service, Carp Management Program Annual Report 2007-2008; Inland Fisheries Service: Hobart, Australia, 2008.

52. IFS. Inland Fisheries Service, Carp Management Program Annual Report 2008-2009; Inland Fisheries Service: Hobart, Australia, 2009.

53. IFS. Inland Fisheries Service, Carp Management Program Annual Report 2009-2010; Inland Fisheries Service: Hobart, Australia, 2010. 